\title{
Malignant PEComa
}

National Cancer Institute

\section{Source}

National Cancer Institute. Malignant PEComa. NCI Thesaurus. Code C121792.

A usually large and aggressive tumor with perivascular epithelioid cell differentiation characterized by the presence of marked nuclear atypia, pleomorphism, increased mitotic activity, necrosis, and infiltrative margins. The most common metastatic sites are liver, lungs, lymph nodes, and bone. 